
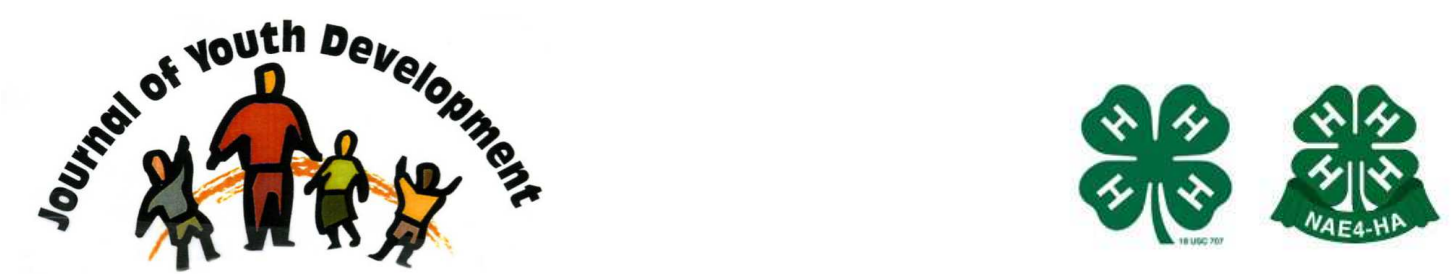

Bridging Research \& Practice

\title{
4-H and 4-H Members in Motion Pictures
}

Jan Scholl

Penn State University

University Park, PA

jscholl@psu.edu 


\title{
JOURNAL OF YOUTH DEVELOPMENT \\ bridging research and practice

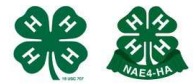

\section{4-H and 4-H Members in Motion Pictures}

\author{
Jan Scholl \\ Penn State University
}

\begin{abstract}
Youth involved in Extension activities were portrayed on film as early as 1913 . This paper provides a summary of the earliest motion pictures in which $4-\mathrm{H}$ and $4-\mathrm{H}$ members were a part. From the more than 400 early Extension films made by USDA, $224-\mathrm{H}$ films were located and described. Hollywood films, with 4-H themes, were found. Reflections on film preservation and availability are addressed as well as the role of film and other media in the early twentieth century.
\end{abstract}

\section{Introduction}

It is difficult to think of anything that has changed more than media-at least in the last 70 years. Though radio had been popular with Cooperative Extension audiences since the 1926 (USDA) Aunt Sammy series, it was 1940 when Murphy conducted the first study on the use of radio in the 4-H program. Phonographic records were sent to the news media as public service announcements for national 4-H events in the 40s, 50s and 60s. Celebrities, such as Bob Hope and Donna Reed, provided endorsements.

Early 4-H songs were also "on vinyl." A Place in the Sun, composed by the famous orchestra leader Fred Waring (1950) for the 4-H Clubs of America, was one of many.

Television, as educational media, was studied in the 50 s and 60 s in conjunction with 4-H projects (Fanning, 1959; Woolman, 1967) and other Extension bulletins (Coolican, 1960; Eyestone, 1966). Educational media specifically designed for minority audiences was investigated by Pinnock (1964) and Koleade (1985). In the 1970s, USDA produced Mulligan Stew. This six-part series taught nutrition education in schools and was evaluated (Nolan, 1970; Shapiro, 1974) as were other educational 4-H television programs in Michigan (Deutschmann, \& McNelly, 1958); Oklahoma (Godard, 1969); Wisconsin (Thompson, 1970), and Minnesota (Olien, Tichenor, \& Donohue, 1972 \& 1975). 
About the same time, slide and cassette tape productions were used for presentations (Carey, 1967; Davis, 1979; Gale, 1984; Lotz 1974; Mortvedt, \& Fain, 1978; Watson, 1975) and promotion (Cox,1983; Gehrs, 1982). Video tapes were also developed for 4-H use and evaluated in the late 1980s (Barkman, 1989 \& 1991; Hall, 1988).

Computers were used to create software used to train 4-H volunteer leaders and staff (Coleman, 1986; Courson, 1999; Doebler, 1988; Ghods, 1979; Goode, 1990; Martin, 1998; Sexton, 2000) and develop 4-H curricula (Bakalar, 1985; Barkley, 1992; Duffey, 1985; Scholl, 1993, 1994, 2003; Vigna, Fairchild, \& Donaldson-Fassett, 2006). The years, starting with 2000, involved 4-H staff and researchers and the use of CDs (Bryant, 2004), news (Boyd, 2010) and social media (Bowen, 2012; Sorenson, 2011; Zammit, 2012).

One of the few areas that have not been studied are the early films involving agricultural youth that were created by USDA and the Hollywood. As many people are interested in historical events and the historical background of the 4-H program, this study was conducted to locate and document these motion pictures.

\section{Objectives}

The purpose of this study was to locate the earliest Extension films (1900-1950) about 4-H youth in order to study the messages portrayed to 4-H members and the film production techniques that were used to depict these messages.

The second purpose of the study was to describe similar Hollywood films, comparing these with the early USDA/Extension developed films.

\section{Methods}

More than 400 Extension films were found in the National Archives (Archives II, College Park, MD) and the Library of Congress film libraries. These include a few created by the University of Georgia during the 1950s and 1960s. A total of 22 films contained content about 4-H members. These silent, black and white (1913-1935) and color films (1940-1970s) were duplicated on VHS tape. Reports and other printed documentation about the films were found in archive collections. Some films were borrowed from a private collection for the study.

The films were investigated using techniques for "eyewitnessing" as outlined in Burke (2001) and Hunt (2010), qualitative methods as described in Berg (2009), and content analysis (Krippendorff, 2004). Three reviewers studied films and noted their impressions. The films were reviewed between three and ten times depending on the content, length of the film, and the need for clarification.

Documentation was noted regarding:

(1) when the films were made,

(2) the location and aspects of film production,

(3) projects and activities that youth participated in,

(4) social contexts and attitudes portrayed by the youth, and

(5) film techniques used by the producers. 
Documentation was sought to describe historical references to the films and any interest expressed by those watching them.

\section{Summary of Findings}

Though most of the early 4-H films were produced in the 1920s, the earliest (available for review) was completed in 1913. Helping the Farmer of Tomorrow shows state agricultural prize winners touring Washington DC, evidently as an award trip for work completed in their communities. There are scenes of young people receiving diplomas from the U.S. Secretary of Agriculture, James Wilson, and tours of Union Station, Continental Hall, The Pan American Union, The White House, and National Zoo.

In the 1910s, several Extension and 4-H program leaders petitioned the film department to make educational films. Proposals were submitted by $\mathrm{O} . \mathrm{H}$. Benson over a number of years. The former Iowa superintendent of schools (1906), credited with the 4-H clover, was one of the first program leaders for boys and girls clubs (early 4-H work). In his teens, he had saved the family farm by selling fresh and canned foods and, later wrote many Extension bulletins for USDA on canning. He felt the media could show appropriate techniques to women and youth to supplement the more time consuming and costly practices of demonstration travel on trains and the movable school. Film was also less cumbersome and breakable than lantern slides, another early technology.

Because of the numerous cases of food poisoning in the news and the continued threat of illness and death, Cured by Canning (1920) was produced. This film shows the methods of food preservation taught to mothers and daughters in Glenwood, Kansas through the formation of Extension canning clubs. The film emphasized the economy and nutritional value of home canned fruits, vegetables and meat.

In the early 1920s, camping was depicted in the films, Club Champions at Camp Vail (1920) and The 4-H Camp for Boys and Girls (1921). Many have never heard of Camp Vail. It was a multistate camp, located in Massachusetts, for the purpose of youth displaying their knowledge through demonstrations, judging, and exhibits. Youth from ten Mid-Atlantic states gave canning and poultry demonstrations at this camp and judged sewing and livestock. The young people also took part in calisthenics, social activities, and wrote letters home. They answered reveille, ate breakfast, and washed dishes. In the mess hall, they chanted:

"Soupie, soupie, soupie, without a string bean Coffee, coffee, coffee the worst I've ever seen, Meatie, meatie, meatie without a streak of lean."

The 4-H Club Camp for Boys and Girls (1921) showed a day's club activities, beginning with reveille, calisthenics, eating breakfast, making beds and constructing a stage. The youth rehearsed a pageant symbolizing the ideals of the $4-\mathrm{H}$ program. In the film, Bill Jones Champion, (1922) calisthenics and attendance at lectures, horse races, and livestock shows were the primary activities.

Young people arriving on the Washington State and University of Idaho campuses were involved in sewing, judging, and other activities in Club, College, Farm and Home (1927). Livestock and corn judging, bee keeping, poultry husbandry, butter making and sewing classes were taught at Louisiana State University's The Short Course (1925) and in A Crop Worth Saving (1925), the Louisiana 4-H members showed livestock and garden produce, and attended 
corn and livestock exhibitions. The main theme of this film was to save the crop of young people for farming and homemaking.

\section{Promotional Films}

Much like Helping the Farmer of Tomorrow (1913), there were films in the 1920s that seemed to reinforce the notion: "Do a good job and you will see famous places and people." 4-H members in Seeing Washington (1924) visit the Lincoln and Jefferson Memorials, the Red Cross Building, and the Smithsonian. In Carry On (1930), participants ride in a flatbed, open-air wagon on Independence Avenue traveling toward the Capital. The film also takes the viewer to the top of the Washington Monument for aerial views of Washington, and then down again to visit the Library of Congress, Mount Vernon, the Smithsonian, Lincoln Memorial, and the Tomb of the Unknown Soldier at Arlington Cemetery. President Hoover delivers a short address to the members. In Personages: Corbett, Hoover, Hyde and Pinchot (1913-1929) Secretary of Agriculture Hyde and Mrs. Herbert Hoover "inspect" an early 4-H encampment on the National Mall.

The film, Payne Fund Students Complete Course (1932), is the only known record of the first college graduates to participate in this year-long research experience in Washington, DC. It was also one of the first USDA films to incorporate sound.

Though many films focused on local, state and national programs, some had more educational goals. In Good Posture Wins (1931), a young girl improves her posture by exercise and selfawareness. Slow motion photography is used to show proper foot alignment while walking. In Home Demonstration Work in the Western United States (1934), an early style show is well supported by community attendance and applause. Unlike 4-H fashion revues of today, the girls literally, "twirl" across the stage.

Scenes of 4-H club meetings may be found in Bill Jones Champion (1922), Secretary of Agriculture Wallace (1924), Good Posture Wins (1931), and later, in A Very Community (1948).

Many of the films created in the 1940 s and 50s, were 4-H project-oriented and some were produced with the aid of an company or corporation. These University of Georgia films depict projects for boys including: Big Steaks (circa 1950s), shows how a young boy raises a steer for his 4-H project. Cotton Pickin'Money (circa 1950s), follows a boy who raises and sells cotton, buying a used car and saving money for next year's seed and for college. Prize-winning pastures in various regions of Georgia were created by boys in 4-H Pastures (circa 1950s). Treasure Land (circa 1950s) shows the inspirational nature of 4-H work. In addition to club activities and raising a calf, a young man performs neighborhood activities, such as cleaning the church grounds. The film, 4-H and the Insect World shows extreme close-ups of insects (for identification) and how to spray fields with insecticide.

There were fewer films with "girls" work. In Teen Togs (sound/color/1944), the benefits of wardrobe planning and learning to sew are shared so teen girls "won't be staying home on a shelf." (The script rhymes throughout the film.)

\section{4-H Films from Fiction}

A few films portray 4-H members in fiction. Under the 4-H Flag (1929) was based on a children's book written by John Case. In the story, a tenant family tries to refurbish a 
dilapidated farm and 4-H members help the family overcome many obstacles. Similar situations stories were presented in Hollywood films.

\section{Hollywood Films}

Several films were created by Hollywood to show the value of 4-H. They often involved the National Committee on 4-H Boys and Girls Clubs staff as consultants. Some of the film stars attended national events where 4-H members were in attendance as preparation for their role. Jane Withers, for example, was reported to have attended the 1941 "Club Convention" in Washington. This film was credited to Secretary of Agriculture Claude R. Wickard and his associate, M. L. Wilson and dedicated to the "thousands of 4-H club leaders throughout the country...." A handful of films are significant because of their subject matter and the actors selected to play the 4-H members:

Young America (1942) was a film about a spoiled city girl, Jane Campbell (played by child actress, Jane Withers) who visits her aunt and uncle on the farm and ends up raising a champion steer. Through many difficult circumstances, she learns that friendship, not winning, is important. This plot is very similar to a picture created in 1961 by Universal Studios called Tomboy and the Champ. Both are focused on girls and livestock projects.

Green Promise (1949) was based on a story written by Monty F. Collins. Like, Under the 4-H Flag (1929), what is featured is the plight of farm families who move from place to place unaware or unable to employ proper crop management procedures to save the soil. In the opening scene, a family moves to a new farm after their previous land "blew away." The farmer father (played by Walter Brennan) is exceedingly ignorant of wise farming and forest practices. He also refuses the aid of the county agent (touted by community members as the "doctor of agriculture and community problems") and is just as stubborn about his leash on family affairs, forcing his will through a pretense of the democratic process. The main story, however, is of his daughter, Susan Walters (played by Natalie Wood) who desperately wants to be a 4-H member so she can finally have something of her own. Susan becomes upset seeing how other children carry on successful projects while she is not allowed to participate. She tries to face the disappointment of her father's decision, but becomes so frustrated she tears up a project book. When her father is bedridden in a farm accident, her older sister and the Extension agent help Susan join the Millwood 4-H Club. Not to be missed is Susan's excitement at reciting the pledge at the club meeting and convincing the local banker to provide a loan for her lamb project. She learns that members "make their own luck."

\section{Discussion}

Unlike the Hollywood films, the early USDA films did not credit any of the actors except one young man named Lyman and an Extension specialist producer, Mignon Quaw (1917-1923). Likewise it is interesting that Hollywood chose an actual 4-H member (from 11,000 applicants) Jeanne LaDuke from Indiana, to play the supporting youth role in Green Promise. As Jessie Wexford, she liked to make biscuits though her brother constantly teased her about them. She was involved in several scenes at the church, the fishing hole, and with "Caesar" her brother's prize bull. She wore a harem dress at the club's Halloween party and chided her brother with statements such as: "now you've done it" and "only a woman would understand."

The early USDA films are not unlike the silent, black and white films of early Hollywood. Some are documentaries or instructional films, but many are stories. The films demonstrate how 
much recreation and exercise were a part of club meetings and camps. The focus of the camp competitions was to show innovative ideas and personal improvement, not so much on "winning." In several films, the "winner" allows the recognition to be given to another member who has been struggling to improve themselves. Camaraderie and teamwork were depicted in many club, camp, and skit scenes.

As a historical reference, the USDA films were developed at the same time Hollywood films featured Mary Pickford, Charlie Chaplin and other early stars. Don Carlos Ellis (1919a \& 1919b) coordinator of the film unit, wrote a series of articles about the motion picture activities at the U.S. Department of Agriculture. "The unit was quite progressive, experimenting with film use before World War I. It recognized the educational value of films in response to a strong demand from its Extension forces." At the time, more than a few filmmakers felt that motion pictures would become effective educational tools for civilian as well as military audiences (Blanchard, 1919; Fleming, 1911).

In a series of trials by Ellis (1919a) and his staff, it was decided that the films were especially effective in "awakening interest and encouraging the reading of publications and further investigations of subjects." Though certain types of films were found to be effective in teaching process and methods, it was felt that films were "merely to supplement and illustrate other methods of instruction (Ellis, 1919b)." For this reason, an array of bulletins and project materials was often shown at the end of the films.

There were some bulletins printed about the films that illustrate how films were shown: wired to a battery of a car outside the meeting room. In one of the films, a farm family receives a flyer in the mail and the family chooses to attend the film to give the children the experience of this new technology (regardless of the topic).

To our $21^{\text {st }}$ century standards, the films stereotype "boy" and "girl" projects and emphasize traditional roles. Yet, the films also depict both boys and girls securing loans, saving money to support their projects, and selecting certain projects in order to attend college. Older teens modeled skills so younger youth could be successful.

There is evidence that these films were very much in demand. Though no specific acknowledgement was made of the popularity of the youth-oriented films, the 250 titles available at USDA in 1930 were mailed out 11,000 times (Eisenhower, \& Chew, 1930).

Probably the greatest endorsement of the early films was provided by Bernice Echols Grant, a Georgia 4-H pioneer, in a book written by her daughter (Echols, 1971). She described the value of the early $4-\mathrm{H}$ films this way:

"Another beyond-description delight was a movie: silent, black and white, poor screen and dim light. The characters jumped and jerked across the stage. But how glorious! It is doubtful if any magnificent film in color and bedecked with Academy Awards has brought more joy to country youth of this generation than that experienced by these [youth] of over a half a century ago." (p. 23). 


\section{Reflections on Film Preservation and Availability}

Though not directly part of the study, the author feels she must comment on the availability of the films as this is the primary question asked when the films are shown.

The films made by USDA were filmed in locations near the land-grant colleges and universities throughout the country. They were made available to Extension educators on loan. Currently, they are available in a film collection at the National Archives (Archives II, College Park, MD) and the National Ag Library. For patrons, the films may be dubbed from old Beta cassettes as the original films are in storage. These duplications are in very poor shape.

Even so, we also should be grateful, that these early films, unlike many others, were valued and saved so that we may still see them. As large a production as Mulligan Stew was, there are only a few copies of the film that still exist in U.S. libraries.

Even into the 1960s, the USDA and commercial films were loaned to 4- $\mathrm{H}$ leaders and articles were written about them in the National 4-H News (1923-1988) magazine. The National 4-H Preservation Committee is currently trying to locate originals and copies of these films. As media technology changes, it is a challenge to preserve film images that are copied and recopied and put into new formats in various states of repair and disrepair.

To locate a copy for viewing, the film center of the National Archives II is located at 8601 Adelphi Road, College Park, MD. The Extension films are listed on-line in record group 33. The NAIL (National Archives Information Locator) may be searched at

http://www.nara.gov/nara/nail.html. The Extension films are best viewed and dubbed on-site. Films may be ordered, but the process is time-consuming and expensive.

The Hollywood film, Green Promise, has been re-mastered and copies are available from internet auction sites and book sellers. The film, Young America, was found in a private collection.

\section{Conclusion}

All of the films reviewed here show how the 4-H program consistently encouraged youth to complete their project work, keep good records, seek opportunities for improvement, and help others. They showed how personal goals were achieved. They are as inspirational for those who know nothing about the 4-H program as for youth who have been enrolled for many years. With quality preservation, vigilance and care, these treasures may be preserved for years to come.

Since the early days, state 4-H programs have made motion pictures of club activities and events. Youth are currently participating in video contests (Krug, 2012). Many are using YouTube and iphones as a way to share short productions with their friends (Rozum, 2013). As media formats change rapidly, the challenge will be in preserving these sketches for the benefit of $4-\mathrm{H}$ members in the future.

As Bill Jones Champion (1922) would say, "Keep On in Club Work!" 


\section{References}

Bakalar, C. (1985). Computer software development: An educational tool for teaching nutrition in Pennsylvania 4-H(Unpublished Masters of Education thesis). Penn State University, University Park, PA.

Barkley, M. (1992). Development of an interactive computer program on cuts of beef for 4-H (Unpublished Masters of Education thesis). Penn State University, University Park, PA.

Barkman, S. (1991). Higher impact instructional videos. West Layfayette, IN: Purdue University.

Barkman, S. (1989). The effect of inserted questions requiring overt responses on learning a complex procedural skills through instructional video (Unpublished Doctor of Philosophy dissertation). Indiana University, Bloomington, IN.

Benson, O.H. (1911-1917). Personal letters of O.H. Benson, Elsie Carper Special Collection. Beltsville, MD: National Agricultural Library.

Berg, B. (2009). Qualitative research methods for the social sciences. Seventh edition. Boston, MA: Allyn \& Bacon.

Blanchard, P. (1919). The motion picture as an educational asset. Educational Film Magazine, 24, 284, 287.

Bowen, R. (2012). Diffusion of social media among county 4-H programs in Tennessee (Unpublished Masters of Science thesis). University of Tennessee, Knoxville, TN.

Boyd, M. (2010). The relationship between adolescents' news media use and civic engagement (Unpublished Masters of Arts thesis). Tufts University, Medford, MA.

Bryant, T. (2004). Development of a food safety education program on CD Rom for $4^{\text {th }}, 5^{\text {th }}$, and $6^{\text {th }}$ grade children (Unpublished Masters of Science thesis). Kansas State University, Manhattan, KS.

Burke, P. (2001). Eyewitnessing: The uses of images as historical evidence. Ithaca, NY: Cornell University Press.

Carey, H. (1967). The effectiveness of colored slides and script for teaching rural fallout protection to high school agricultural classes and 4- $\mathrm{H}$ clubs (Unpublished Masters of Education thesis). Penn State University, University Park, PA.

Case, J. (1927). Under the 4-H flag. Philadelphia, PA: Lippincott.

Coleman, Q. (1986). Individual characteristics and organizational factors that influence the use of the microcomputer by Maryland Cooperative Extension Service field faculty. (Unpublished doctoral dissertation). University of Maryland, College Park, MD. 
Coolican, P. (1960). A study of the effectiveness of teaching by television versus teaching by the use of an extension bulletin (Unpublished Masters of Science thesis). Michigan State University, East Lansing, MN.

Courson, J. (1999). An assessment of computer-related skill needed and possessed by county extension professionals in the Mississippi State University Extension Service (Unpublished Doctor of Education dissertation). Mississippi State University, Mississippi State, MS.

Cox, R. (1983). Literature review: 4-H camping program and slide set/related materials for promotion of northwestern/northcentral Pennsylvania regional camping program. (Unpublished Masters of Extension thesis). Penn State University, University Park, PA.

Davis, R. (1979). Development of a slide series on showmanship of horses at halter (Unpublished Masters of Science thesis). Southern Illinois University, Carbondale, IL.

Deutschmann, P., \& McNelly, J. (1958). Impact of a 4-H television series. East Lansing, MI: Michigan State University.

Doebler, M. (1988). Microcomputers and 4-H volunteer leaders: $A$ study to determine attitudes, experiences and self-perceived training needs of Pennsy/vania 4- $H$ volunteer leaders with regard to microcomputer use in traditional 4-H programs (Unpublished Masters degree thesis). Penn State University, University Park, PA.

Duffey, D. (1985). A study to develop and test a computer literacy curriculum of the 4-H program of the Texas Agricultrual Extension Service (Unpublished Doctor of Education dissertation). Texas A \& M University, College Station, TX.

Echols, K. (1971). Bernice Echols Grant-4-H pioneer. Athens, GA: University of Georgia.

Eisenhower, M., \& Chew, A. (1930). The United States Department of Agriculture: Its Growth structure and function, USDA Miscellaneous Publication 88, p. 3.

Ellis, C. (1919a, January). Motion pictures in agricultural education. Part 1. Educational Film Magazine, 1, 19.

Ellis, C. (1919b, February). Motion pictures in agricultural education. Part 2: Conclusion. Educational Film Magazine, 1, 13.

Eyestone, M. (1966). A comparison of the effectiveness of bulletin, film and lecture, with and without discussion, in presenting research findings (Unpublished Doctor of Philosophy dissertation). University of Wisconsin, Madison, WI.

Fanning, P. (1959). An evaluation of teaching the 4-H electric project by the use of television (Masters of Science thesis). University of Idaho, Moscow, ID.

Fleming, P. (1911). Moving pictures as a factor in education. Educational Film Magazine, 18, 336-352.

Gale, C. (1984). Teen programs and slide set (Masters of Extension project). Penn State University, University Park, PA. 
Gehrs, C. (1982). A promotional slide-tape presentation for the Elkhart County Mini-4-H program (Unpublished Masters of Arts thesis). Ball State University, Muncie, IN.

Ghods, M. (1979). Michigan extension agents' attitudes toward computers and computerized Extension forward planning and consulting programs: The TELPLAN system.

Godard, C. (1969). Effects of voluntary exposure to 4-H programs through television (Unpublished Masters of Science thesis). Oklahoma State University, Stillwater, OK.

Goode, D. (1990). Computer applications and computer technology transfer by Mississippi Extension personnel: An evaluation of involvement, competencies and training. (Unpublished Doctoral of Education dissertation). Mississippi State University, Mississippi State, MS.

Hall, J. (1988). A follow-up evaluation of "Nutrition in Action": A videotaped course for 4-H leader education (Unpublished Master of Education thesis). Penn State University, University Park, PA.

Hunt, L. (2010). Capturing the moment: Images and eyewitnessing in history. Journal of Visual Culture, $9(3), 259-271$.

Koleade, R. (1985). Effective communication media for potential minority 4-H youth in Franklin County as perceived by the county 4-H minority advisors (Unpublished Masters of Science thesis). Ohio State University, Columbus, $\mathrm{OH}$.

Krippendorff, K. (2004). Content analysis: An introduction to its methodology. Thousand Oaks, CA: Sage.

Lotz, L. (1974). The attitudes and learning levels of a 4-H audience to the use of educational television (Unpublished Master of Science thesis). Ohio State University, Columbus, $\mathrm{OH}$.

Martin, B. (1998). Computer anxiety levels of Virginia Cooperative Extension field personnel (Unpublished Doctor of Philosophy dissertation). Virginia Polytechnic Institute and State University, Blacksburg, VA.

Mortvedt, M., \& Fain, S. (1978). An evaluation of the audio-cassette series, "The 4-H Volunteer Community." Columbus, $\mathrm{OH}$ : Ohio State University.

Murphy, L. (1940). The use of radio in 4-H club work (Unpublished Masters of Arts thesis). George Washington University, Washington, DC.

National 4-H News. (1923-1988). http://4-hhistorypreservation.com/History/Nat_4-H_News/

Nolan, J. (1970). An evaluation of the television series, Mulligan Stew. Columbia, MO: University of Missouri.

Olien, C., Tichenor, P., \& Donohue, G. (1972). Educational television: An evaluation model. St. Paul, MN: University of Minnesota. 
Olien, C., Tichenor, P., \& Donohue, G. (1975). A systems evaluation of a purposive message: The Mulligan Stew ETV project. St. Paul, MN: University of Minnesota.

Pinnock, T. (1964). Comparison of the effectiveness of film and bulletin in transmitting knowledge to Negro 4-H club local leaders in Alabama and Caucasian 4-H club local leaders in Wisconsin (Unpublished Doctor of Education dissertation). University of Wisconsin, Madison, WI.

Quaw, M. (1917-1921). Progress reports. Bozeman, MT: Montana Cooperative Extension Service (currently found in the Montana State University archives).

Scholl, J. (1993). Comparison of traditional and electronic methods of developing curriculum for Extension. Summaries of Research in Agricultural Extension, 86-87.

Scholl, J. (1994). Developing 4-H curricula on an electronic database. Journal of Extension, 32(2), on-line.

Scholl, J. (2003). Curriculum development: Comparing traditional and on-line practices. Journal of Family and Consumer Sciences, 94(4), 87-93.

Sexton, J. (2000). A comparison of traditional and World Wide Web methodologies, computer anxiety, and higher order thinking skills in the in-service training of Mississippi 4- $\mathrm{H}$ Extension agents (Unpublished Master of Science thesis). Mississippi State University, Mississippi State, MS.

Shapiro, S. (1974). An evaluation of the Mulligan Stew 4-H television series. Washington, DC: USDA 4-H Youth Development Division.

Sorenson, M. (2011). A qualitative study of 4-H state and field faculty use of social media to communicate with youth, volunteers, and stakeholders (Unpublished Masters of Science thesis). Louisiana State University, Baton Rouge, LA.

Thompson, J. (1970). Evaluation of educational television in university Extension youth programming. Madison, WI: University of Wisconsin.

USDA. (1926). Homemaker's Chats (Aunt Sammy scripts). Beltsville, MD: National Agricultural Library.

Vigna, D., Fairchild, P., \& Donaldson-Fassett, J. (2006). Innovative online curriculum writing: A practical approach for multiple authors/multiple approaches. Journal of Extension, 44(4), online. Available at: http://www.joe.org/2006august/w4.php.

Waring, F. (1950). A Place in the Sun (sound recording). New York: Decca Records.

Watson, J. (1975). Evaluation of food and nutrition concepts of Iowa youth in the Expanded Nutrition Program using a slide-tape presentation (Unpublished Masters of Science thesis). Iowa State University, Ames, IA.

Woolman, R. (1967). Teaching 4-H project work through television (Unpublished Master's of Education thesis). Colorado State University, Fort Collins, CO. 
Zammit, Kali. (2012). Examining the use of social media among 4-H alumni in Louisiana. (Unpublished Master of Science thesis). Louisiana State University, Baton Rouge, LA.

\section{Film References}

RKO Pictures, Inc. (1949). Green Promise (released as Raging Waters in the United Kingdom and Verdes Horizontes in Mexico), 100 minutes.

Twentieth Century-Fox. (1942). Young America, 73 minutes.

USDA Extension Service. (1925). A Crop Worth Saving, 33(245), 61 minutes.

USDA Extension Service. (1922). Bill Jones Champion, 33(205), 10 minutes.

USDA Extension Service. (1930). Carry On, 33(325), 24 minutes.

USDA Extension Service. (1920). Club Champions at Camp Vail, 33(44), 12 minutes.

USDA Extension Service. (1927). Club, College, Farm and Home, 33(298), 4 minutes.

USDA Extension Service. (1920). Cured by Canning, 33(50), 13 minutes.

USDA Extension Service. (1921). The 4-H Camp for Boys and Girls, 33(19), 16 minutes.

USDA Extension Service. (1931). Good Posture Wins, 33(399), 30 minutes.

USDA Extension Service. (1913). Helping the Farmer of Tomorrow, 33(28), 26 minutes.

USDA Extension Service. (1934). Home Demonstration Work in the Western States, 33, 33 minutes.

USDA Extension Service. (1932). Payne Fund Students Complete Course, 33(442), 3 minutes. USDA Extension Service. (1913-1929). Personages: Corbett, Hoover, Hyde and Pinchot, Series M, Item 2, 10 minutes.

USDA Extension Service. (1924). Secretary of Agriculture Wallace. 33(14), no length specified.

USDA Extension Service. (1976). Secretary Butz on 4-H. 33(1790), 4 minutes.

USDA Extension Service. (1924). Seeing Washington. 33(220), 17 minutes.

USDA Extension Service. (1925). The Short Course. 33(269), 15 minutes.

USDA Extension Service. (1929). Under the 4-H Flag, 63 minutes.

USDA. (1970s). Mulligan Stew, 180 minutes.

Universal Studios. (1961). Tomboy and the Champ, 92 minutes. 
University of Georgia. (circa 1940s). Teen Togs, 33(19), 10 minutes, sound/color.

University of Georgia. (1948). A Very Community, 33(22), 10 minutes, sound/color.

University of Georgia. (circa 1950s). Big Steaks, 33(18), 14 minutes, sound/color.

University of Georgia (circa 1950s). Cotton Pickin'Money, 33(12), undetermined length.

University of Georgia. (circa 1950s). 4-H and the Insect World, 33(13), 26 minutes, sound/color.

University of Georgia. (circa 1950s). 4-H Pastures, 33(7), no length of time specified.

University of Georgia. (circa 1950s). Treasure Land, 33(8), 25 minutes, sound/color.

(C) Copyright of Journal of Youth Development Bridging Research and Practice. Content may not be copied or emailed to multiple sites or posted to a listserv without copyright holder's express written permission. Contact Editor at: patricia.dawson@oregonstate.edu for details. However, users may print, download or email articles for individual use. 